\title{
Front Matter: Volume 11435
}

, "Front Matter: Volume 11435," Proc. SPIE 11435, 2019 International Conference on Optical Instruments and Technology: Optical Communication and Optical Signal Processing, 1143501 (12 March 2020); doi: $10.1117 / 12.2566266$

SDIE Event: 2019 International Conference on Optical Instruments and Technology, 2019, Beijing, China 


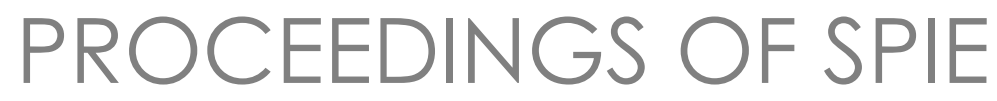

\section{International Conference on Optical Instruments and Technology}

\section{Optical Communication and Optical Signal Processing}

Jian Chen

Yi Dong

Fabien Bretenaker

Editors

26-28 October 2019

Beijing, China

Sponsored by

CIS-China Instrument and Control Society (China)

Cosponsored and Published by

SPIE 
The papers in this volume were part of the technical conference cited on the cover and title page. Papers were selected and subject to review by the editors and conference program committee. Some conference presentations may not be available for publication. Additional papers and presentation recordings may be available online in the SPIE Digital Library at SPIEDigitalLibrary.org.

The papers reflect the work and thoughts of the authors and are published herein as submitted. The publisher is not responsible for the validity of the information or for any outcomes resulting from reliance thereon.

Please use the following format to cite material from these proceedings:

Author(s), "Title of Paper," in 2019 International Conference on Optical Instruments and Technology: Optical Communication and Optical Signal Processing, edited by Jian Chen, Yi Dong, Fabien Bretenaker, Proceedings of SPIE Vol. 11435 (SPIE, Bellingham, WA, 2020) Seven-digit Article CID Number.

ISSN: 0277-786X

ISSN: 1996-756X (electronic)

ISBN: 9781510636484

ISBN: 9781510636491 (electronic)

Published by

SPIE

P.O. Box 10, Bellingham, Washington 98227-0010 USA

Telephone +1 3606763290 (Pacific Time) · Fax +1 3606471445

SPIE.org

Copyright (c) 2020, Society of Photo-Optical Instrumentation Engineers.

Copying of material in this book for internal or personal use, or for the internal or personal use of specific clients, beyond the fair use provisions granted by the U.S. Copyright Law is authorized by SPIE subject to payment of copying fees. The Transactional Reporting Service base fee for this volume is $\$ 21.00$ per article (or portion thereof), which should be paid directly to the Copyright Clearance Center (CCC), 222 Rosewood Drive, Danvers, MA 01923. Payment may also be made electronically through CCC Online at copyright.com. Other copying for republication, resale, advertising or promotion, or any form of systematic or multiple reproduction of any material in this book is prohibited except with permission in writing from the publisher. The CCC fee code is 0277 $786 \mathrm{X} / 20 / \$ 21.00$.

Printed in the United States of America by Curran Associates, Inc., under license from SPIE.

Publication of record for individual papers is online in the SPIE Digital Library.

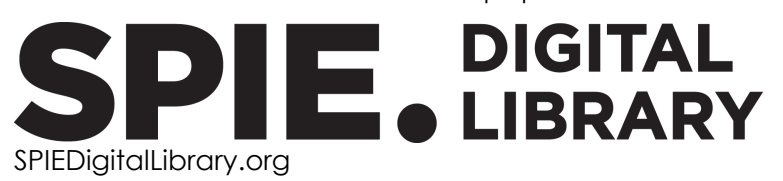

Paper Numbering: Proceedings of SPIE follow an e-First publication model. A unique citation identifier (CID) number is assigned to each article at the time of publication. Utilization of CIDs allows articles to be fully citable as soon as they are published online, and connects the same identifier to all online and print versions of the publication. SPIE uses a seven-digit CID article numbering system structured as follows:

- The first five digits correspond to the SPIE volume number.

- The last two digits indicate publication order within the volume using a Base 36 numbering system employing both numerals and letters. These two-number sets start with 00, 01, 02, 03, 04, 05, 06, 07, 08, 09, OA, OB ... 0Z, followed by 10-1Z, 20-2Z, etc. The CID Number appears on each page of the manuscript. 


\title{
Contents
}

\author{
$\checkmark \quad$ Authors \\ vii Symposium Committees \\ ix Conference Committee \\ xi Introduction \\ xiii Conference Organizers
}

OPTICAL COMMUNICATION AND OPTICAL SIGNAL PROCESSING

1143502 Invalid spectrum rate based scheduling for advance reservation services in elastic optical networks [11435-2]

1143503 Spectrum defragmentation based on path-switching mechanism for $1+1$ protection in elastic optical networks [11435-3]

1143504 Leaf-looping based multicast protection algorithm for elastic optical network [11435-4]

1143505 Spectrum defragmentation in flexible grid optical networks (Invited Paper) [1 1435-6]

1143506 Research on ultrathin silicon-based electro-optic modulators [11435-7]

$1143507 \quad$ A nonlinear tuning compensation method based on homomorphic deconvolution for OFDR systems (Invited Paper) [11435-8]

1143508 Nonlinearity estimation method based on error vector correlation function in coherent optical fiber transmission systems [11435-9]

1143509 Polarization state persistence characteristics in wet haze within PM2.5 for forward transmission [11435-10]

11435 OA Design of annular blazed grating for rotating beam [1 1435-13]

11435 OB A method for complex spectrum analysis of modulated optical signal [11435-15]

11435 OC EHD-printing technology: a novel approach to THz broadband absorber fabrication (Invited Paper) [11435-19]

11435 OD An improved k-means method based indoor visible light localization scheme [11435-21] 
11435 OE NOMA-based visible light non-pre-equalization communication system [1 1435-22]

11435 OF Photonic devices based on antisymmetric Bragg gratings (Invited Paper) [1 1435-23]

11435 OG Photonics-based inverse synthetic aperture radar for near-field RCS calculation [11435-26]

$11435 \mathrm{OH} \quad$ 6G: network visions and requirements for next generation optical networks (Invited Paper) [1 1435-27]

$11435 \mathrm{Ol} \quad$ Combined routing and core-spectrum assignment scheme based on spectrum status for spatial division multiplexing elastic optical networks [1 1435-28]

$114350 \mathrm{~J} \quad$ When virtual network functions are deployed in network resource virtualized elastic optical networks (Invited Paper) [1 1435-30]

11435 OK Fountain clocks comparisons in Beijing area [11435-35]

$11435 \mathrm{OL}$ Time and frequency transfer and synchronization through the optical fiber [1 1435-36] 


\section{Authors}

Numbers in the index correspond to the last two digits of the seven-digit citation identifier (CID) article numbering system used in Proceedings of SPIE. The first five digits reflect the volume number. Base 36 numbering is employed for the last two digits and indicates the order of articles within the volume. Numbers start with 00, 01, 02, 03, 04, 05, 06, 07, 08, 09, OA, OB...0Z, followed by 10-1Z, 20-2Z, etc.

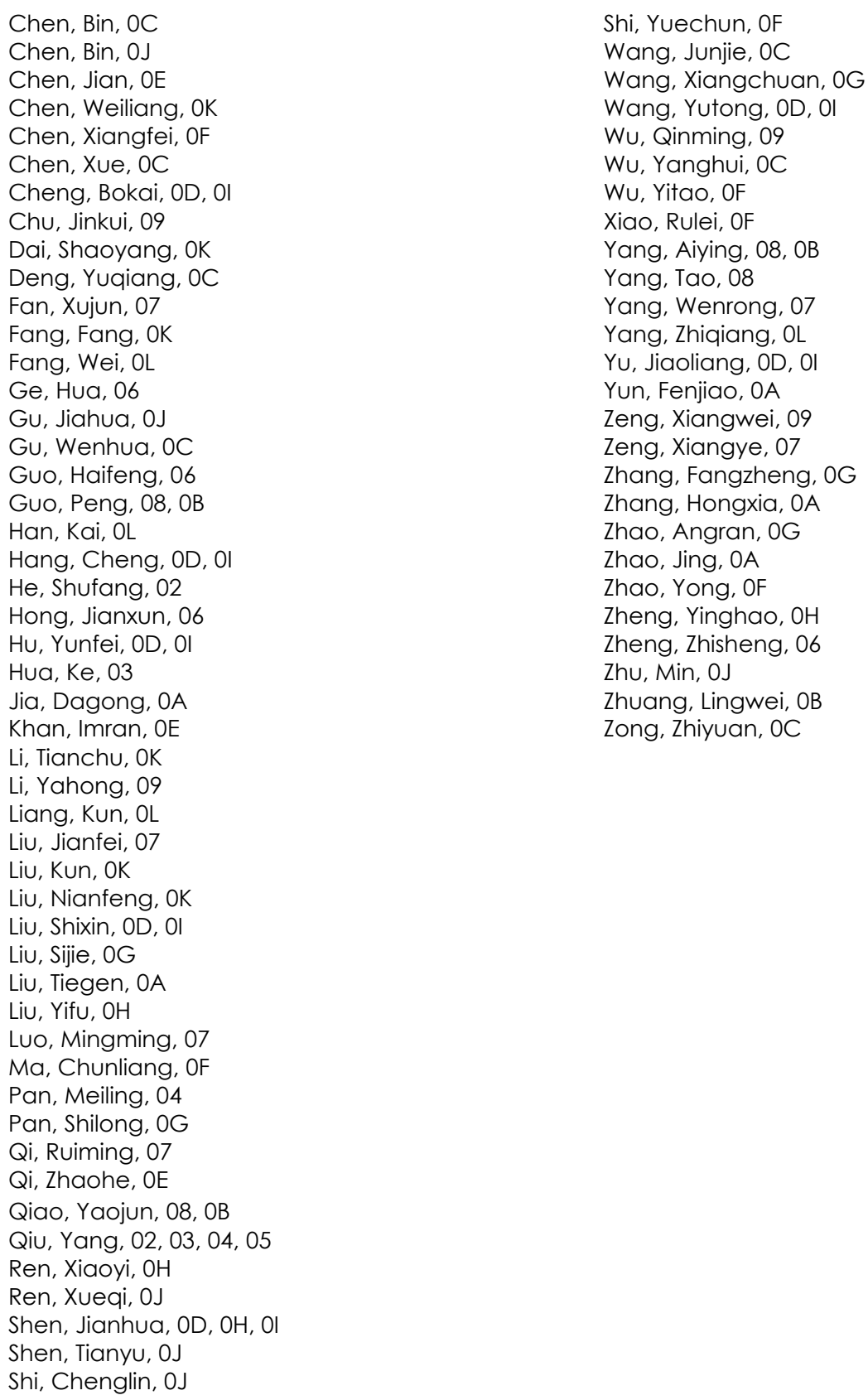

Shi, Yuechun, OF

Wang, Junjie, OC

Wang, Xiangchuan, OG

Wang, Yutong, OD, Ol

Wu, Qinming, 09

Wu, Yanghui, OC

Wu, Yitao, OF

Xiao, Rulei, OF

Yang, Aiying, 08, OB

Yang, Tao, 08

Yang, Wenrong, 07

Yang, Zhiqiang, $\mathrm{OL}$

YU, Jiaoliang, OD, OI

Yun, Fenjiao, OA

Zeng, Xiangwei, 09

Zeng, Xiangye, 07

Zhang, Fangzheng, OG

Zhang, Hongxia, OA

Zhao, Angran, OG

Zhao, Jing, OA

Zhao, Yong, OF

Zheng, Yinghao, $\mathrm{OH}$

Zheng, Zhisheng, 06

Zhu, Min, OJ

Zhuang, Lingwei, OB

Zong, Zhiyuan, OC 
Proc. of SPIE Vol. 11435 1143501-6

\section{Downloaded From: https://www.spiedigitallibrary.org/conference-proceedings-of-spie on 26 Apr 2023
Terms of Use: https://www.spiedigitallibrary.org/terms-of-use}




\section{Symposium Committees}

Symposium Chairs

Zheng You, CIS (China), Tsinghua University (China)

Jim M. Oschmann, Ball Aerospace (United States)

Symposium Committee

Tianchu Li, National Institute of Metrology (China)

Songlin Zhuang, University of Shanghai for Science and Technology (China)

Liwei Zhou, Beijing Institute of Technology (China)

Shenghua Ye, Tianjin University (China)

Yimo Zhang, Tianjin University (China)

Guangjun Zhang, Southeast University (China)

Technical Program Chair

Guofan Jin, Tsinghua University (China)

Technical Program Co-chairs

Jinxue Wang, SPIE

Tiegen Liu, Tianjin University (China)

Local Organizing Committee Chair

Youhua Wu, China Instrument and Control Society (China)

Local Organizing Committee Co-chairs

Guoqiang Ni, Beijing Institute of Technology (China)

Qun Hao, Beijing Institute of Technology (China)

General Secretary

Tong Zhang, China Instrument and Control Society (China)

Administrative Vice General Secretaries

Yu-nan Sun, Beijing Institute of Technology (China)

Liquan Dong, Beijing Institute of Technology (China) 
Vice General Secretaries

Yuejin Zhao, Beijing Institute of Technology (China)

Cunlin Zhang, Capital Normal University (China)

Local Organizing Committee

Hongda Chen, Institute of Semiconductors, CAS (China)

Xuping Zhang, Nanjing University (China)

Shangzhong Jin, China Jiliang University (China)

Libo Yuan, Guilin University of Electronic Technology (China)

Yongcai Guo, Chongqing University (China)

Tian Lan, Beijing Institute of Technology (China)

Cuiling Li, Beijing Institute of Technology (China) 


\title{
Conference Committee
}

\author{
Conference Chairs
}

Jian Chen, Nanjing University of Posts and Telecommunications (China)

Yi Dong, Shanghai Jiao Tong University (China)

Fabien Bretenaker, Laboratoire Aimé Cotton (France)

\section{Conference Program Committee}

Wenshan Cai, Georgia Institute of Technology (United States)

Lu Chao, Hong Kong Polytechnic University (Hong Kong, China)

Zabih Ghassemlooy, Northumbria University (United Kingdom)

Hoon Kim, Korea Advanced Institute of Science \& Technology

(Korea, of Republic)

Zhaohui Li, Sun Yat-sen University (China)

Wen-Di Li, The University of Hong Kong (Hong Kong, China)

JianGuo Liu, Institute of Semiconductors, CAS (China)

Hai Ming, University of Science and Technology of China (China)

Tao Pu, PLA University of Science and Technology (China)

Ming Tang, Huazhong University of Science \& Technology (China)

Chao Wang, University of Kent (United Kingdom)

Yixin Wang, Institute for Information Communication Research of A*STAR

(Singapore)

Yuncai Wang, Guangdong University of Technology (China)

Kenneth K. Y. Wong, The University of Hong Kong (Hong Kong, China)

Chongqing Wu, Beijing Jiaotong University (China)

Jian Wu, Beijing University of Posts and Telecommunications (China)

Li Xia, Huazhong University of Science \& Technology (China)

Xiaoke Yi, The University of Sydney (Australia)

Changyuan Yu, Hong Kong Polytechnic University (Hong Kong, China)

Jinlong Yu, Tianjin University (China)

Song Yu, Beijing University of Posts and Telecommunications (China)

Shaoliang Zhang, NEC Corporation of America (United States)

Xiaoping Zheng, Tsinghua University (China)

Zheng Zheng, Beihang University (China)

Wende Zhong, Nanyang Technological University (Singapore)

Conference Secretary

Jun Wang, Nanjing University of Posts \& Telecommunications (China)

Session Chairs

1 Optics Communication \& Processing I

Yuechun Shi, Nanjing University (China) 
2 Optics Communication \& Processing II

Yang Qiu, Southwest Minzu University (China)

3 Optics Communication \& Processing III Min Zhu, Southeast University (China)

4 Optics Communication \& Processing IV

Xia Yu, Beihang University (China) 


\section{Introduction}

The advent and progress of novel optoelectronics devices and components, including nano-photonics devices and integrated optics, allow achieving novel optical signal processing systems and subsystems. This would lead to the realization of advanced optical communication systems and networks, optical measurement technologies, and other novel applications. The development of these techniques will facilitate and expedite the implementation of optical system in all aspects and represent an impressive feat of science and technology in these fields.

The topics of the Optical Communication and Optical Signal Processing conference within the Optical Instruments and Technology 2019 symposium covered integrated photonic, novel optoelectronic devices and technologies, emerging optoelectronic system and subsystems, and their applications in optical signal processing, optical measurement, sensing, and optical communication systems and networks. More than 21 presentations were accepted as part of this conference, all of which reported the state-of-the-art progresses, results, and achievements in the relevant communities.

\section{Jian Chen Yi Dong Fabien Bretenaker}


Proc. of SPIE Vol. 11435 1143501-12

Downloaded From: https://www.spiedigitallibrary.org/conference-proceedings-of-spie on 26 Apr 2023 Terms of Use: https://www.spiedigitallibrary.org/terms-of-use 


\section{Conference Organizers}

Opto-Electronic-Mechanic Technology and System Integration Chapter, CIS (China)

Committee on Optoelectronic Technology, COS (China)

Committee on Optics, China Ordnance Society (China)

Optical Instrument Chapter, CIS (China)

Beijing Institute of Technology (China)

Tianjin University (China)

Tsinghua University (China)

Peking University (China)

Nanjing University (China)

Zhejiang University (China)

Nankai University (China)

Capital Normal University (China)

Beijing University of Posts and Telecommunications (China)

Chongqing University (China)

University of Shanghai for Science and Technology (China)

Instrument Society of America (United States)

Institute of Measurement and Control (United Kingdom)

Hong Kong Institution of Engineers (Hong Kong, China)

The Society of Measurement and Control (Japan) 
Proc. of SPIE Vol. 11435 1143501-14

Downloaded From: https://www.spiedigitallibrary.org/conference-proceedings-of-spie on 26 Apr 2023 Terms of Use: https://www.spiedigitallibrary.org/terms-of-use 